$2021 \mid$ HaU: Journal of Ethnographic Theory 11 (1): 153-173

SPECIAL ISSUE

FERNANDO ORTIZ: CARIBBEAN AND MEDITERRANEAN

COUNTERPOINTS

LINGUISTIC PERSPECTIVES

\title{
The legacy of Ortiz's Yorubization of Lucumí
}

\author{
Translation as transculturation
}

Amanda Villepastour, Cardiff University

The contemporary retranslation and circulation of Lucumí songs for the orishas (deities) among devotees and scholars in Cuba inadvertently reproduces both the sources and methods of Ortiz's earliest linguistic ventures and reinforces his enduring influence on popular understandings of Santería's utterances. This article draws on research in Cuba in 2018 in partnership with a Nigerian priestess, which revealed the processes, aspirations, and mixed results of contemporary Lucumí song translation efforts. As many Cuban priests granted her religious authority largely on the basis of her Yoruba language knowledge, the hierarchies of translation revealed themselves within a changing global setting. While Ortiz's theory of transculturation recognized the agency of subaltern groups in stimulating cultural change, this article demonstrates that translation is an intrinsically asymmetrical intercultural communication. The linguistic processes of contemporary Nigerian-Cuban priestly encounters resemble Ortiz's philological speculations, yet may also engender change and sustained religious influence.

Keywords: Santería, music, Yoruba, translation studies, transculturation, Lucumí

This article investigates the enduring influence of the Cuban ethnographer Fernando Ortiz (1881-1969) on popular and scholarly understandings of the sacred utterances of the Afro-Cuban spiritual tradition Regla de Ocha (popularly known as Santería). The primary lexicon of Regla de Ocha, Lucumí, which was identified as deriving from Yoruba by Ortiz over a hundred years ago, is employed in oral and written divination texts and prayers and is performed in devotional songs. The latter provided the core focus of research undertaken in Cuba in 2018 in a collaboration with Yoruba priestess Doyin Faniyi from Osogbo, Nigeria, whose presence provided the opportunity to explore the methods and social dynamics of contemporary Lucumí translation in situ. By conducting ethnography in ceremonies, close observation of the processes and strategies Doyin and the Cubans employed to translate Lucumí, and through ret- rospective analysis of their translation outcomes, this research problematizes the Lucumí translation methods and conclusions that devotees and scholars have inherited from Ortiz's writings.

The influence of Ortiz on Afro-Cuban studies, a field that he established in the early twentieth century, was profound both during his lifetime and posthumously through his substantial interdisciplinary publications. Beyond his extensive ethnographic and historical output, Ortiz's theory of transculturation is his foremost theoretical contribution and remains especially important across the humanities in Latin American studies. A revision of Herskovits's application of acculturation, which describes the one-way assimilation process of subaltern groups into the more powerful host society, Ortiz's transculturation theory acknowledges the multidirectional cultural exchanges between subaltern and 
prevailing groups "to express the highly varied phenomena that have come about in Cuba as a result of the extremely complex transmutations of culture that have taken place here" ([1940] 1995: 98).

Ortiz related transculturation directly to music, and may have first named his new theory in a public presentation of Santería music in 1937, which provided much of the content for his revised paper "La música religiosa de los yorubas entre los negros cubanos" (19451946):

Today I discuss three moments in the transculturation of Yoruba or Lucumí music in Cuba. The first is its pure period, that of its orthodox religion and liturgy. The second is still associated with black music, but of a mixed sort involving heterodox religious practices and syncretic ritual. The third period, that of the present, involves secularization and cultural fusion. Three periods: African Lucumí, Cuban Lucumí, and mulatto Lucumí. ${ }^{1}$

The tripartite translation encounter I analyze in this paper processes repertoire within Ortiz's first category, although a good deal of "cultural fusion" had already taken place in the formation of this repertoire. This article is most concerned with transculturation as applied to language and music as the two media are inextricably linked. As this article illustrates, transculturation continues to be a useful theoretical framework for crosscultural encounters between musicians, who engage unselfconsciously in democratic processes of exchange within a "dynamic flow of cultural interchange," and "mutual alteration," to borrow Bill Ashcroft's words to define transculturation (2001:24,122). The overarching narrative of this article sheds light on how Ortiz's written output continues to shape the discourse about AfroCuban religions, music, and language, as well as the contemporary (re)translation and circulation of transcribed Lucumí songs among devotees and scholars in Cuba and beyond.

Contemporary attempts to translate Lucumí inadvertently reproduce Ortiz's earliest linguistic methods, which began with his handwritten offering as a fourteenyear-old, Culecció d'els mals noms de Ciutadella (1895). This fledgling linguistic research project was likely inspired by his teacher in Menorca, Joan Benejam, who published Vocabulario menorquín-castellano in 1895. Where Ortiz's first compiled vocabulary documented a

1. Translation by Moore (Ortiz and Moore 2018: 189-190). living dialect in Menorca, Menorquin, in which he was fluent, his early Lucumí translations were prepared with secondary sources and without ethnography among the Cuban community he identified as Yoruba.

\section{Lucumís Yoruba legacy from Ortiz's writings}

As I have detailed elsewhere (Villepastour 2019), by the 1940s at latest, a former language called Lucumí had passed through attrition, where descendants of firstlanguage Lucumí speakers had "preserved increasingly fragmented and unintelligible texts passed on by enslaved forebearers. . . . Cuban Lucumí, thus, may appear vestigial - carefully preserved but a relic, nonetheless" (Wirtz 2007: 111). By linguistic definitions, this "relic" is a lexicon (i.e., a relatively static corpus of memorized words and phrases with little or no syntax or capacity for generative communication) whose semantic meaning is largely interpretive and dependent on written sources. By contrast, a language (such as Yoruba) must, by definition, draw from a comprehensive grammatical system for generative communication. With the exception of secular folkloric performance, Lucumí is rarely uttered outside of ritual contexts. It is generally performed as heightened speech (such as chanted divination texts and prayers) or is sung. The majority of babalawos (divining priests in the Ifá cult) and santeros (Santería initiates) who regularly use Lucumí have partial and ambiguous semantic comprehension and use the lexicon to communicate with the orishas (deities) through incantations, prayers, and songs. ${ }^{2}$ It is rarely used to communicate with other people as its generative possibilities are so limited, yet Lucumí is routinely described by scholars as a form or dialect of Yoruba (a language of contemporary southwest Nigeria and southern Benin) spoken in Cuba (e.g., Otero 2010: 167; K. Abimbola 2006: 30; Ayorinde 2004: 179; Ramos 2011: 328). By 1948 when anthropologist William Bascom undertook his research in Cuba, his fieldnotes reveal that he had difficulty finding anyone who could use Lucumí for generative speech (Villepastour 2019).

Although Lucumí has been of interest to scholars across the humanities, it has had little interrogation by linguists. At a time when relatively little was known about the utterances of Cuba's freed slaves and slave descendants, Ortiz harnessed the research of Raymundo

2. Cubans use the term oricha, derived from Yoruba òrișà but I use the English spelling of this and other Lucumí words for ease of reading. 
Nina Rodriguez (1862-1906) in Salvador, Brazil, where 40 percent of slaves spoke proto-Yoruba dialects (Eltis 2004: 32-33). ${ }^{3}$ Ortiz used secondary sources to analyze the available linguistic data of African vernaculars at the time in Cuba, and in Hampa afro-cubana: Los negros brujos (1906) he boldly asserted the correspondence between Lucumí in Cuba and Yoruba in southwest Nigeria. There may have been previous efforts to translate Lucumí into Spanish, but it was Ortiz's early text that shaped his own research, that of others who followed his linguistic model (particularly Lydia Cabrera), and, eventually, orisha devotees around the world. But Ortiz's declaration that "the Lucumís abound in Cuba" (2011:29) and his high estimation of Lucumí linguistic correspondence to Yoruba do not align neatly with the increasingly detailed data emerging about the ethnic composition of slave populations in nineteenthcentury Cuba. According to Eltis (2004: 32-33),

Cuba in particular ... drew significant numbers of Africans from all parts of sub-Saharan Africa except Senegambia and the northeast coast. Yoruba speakers cannot have accounted for more than 12 percent of Cuban arrivals. ... In Cuba, in any given year in the nineteenth century, the Yoruba had no choice but to mingle on the plantations of western Cuba with large numbers of Susu from Sierra Leone/Guinea-Conakry, with Igbo from throughout what is now southeast Nigeria, Yao from southeast Africa, and Lunda from the Kasai Valley in Angola, with no single group numerically dominant. The island, in fact, received the greatest mix of African peoples of any large region in the Americas.

In view of the relatively small proportion of Yoruba speakers at any one time in Cuba alongside what is known about the formation of creoles and pidgins in multilinguistic environments, it would be surprising if a form of Yoruba was a dominant African lingua franca on the island at the beginning of the twentieth century. Although Yoruba may have been an important trading language in Havana among emancipados and Yoruba

3. The development of the Yoruba koiné, also known as literary, standard, or common Yoruba, was self-consciously initiated by freed slave and missionary Samuel Crowther (1809-1891). Comprising various dialects in Yorubaland, Hausa, Arabic, and the lexical influence of English, modern Yoruba did not fully emerge until the late nineteenth century (Fagborun 1994). networks moving between Havana and Lagos in the mid-nineteenth century (Otero 2010), ${ }^{4}$ several factors likely made it unsustainable in Cuba. Given the heterogeneous composition of Lucumí ethnicity, the vernacular that evolved had wider influences that Yoruba.

As Palmié (1993: 346) explains, discrete African language communities were more likely to congregate voluntarily in cabildos de nación in urban settings than within controlled plantation environments. Nevertheless, towards the end of the nineteenth century, entry into the orisha cults housed in cabildos was not only facilitated by consanguineous affiliations, but one could "'become' Lucumí through initiation into the 'Lucumí religion"” (Brown 2003: 28) as as was the case in Africa (Barber 1981). Accordingly, Yoruba would not have been a mother tongue for all congregants in Lucumí-identified cabildos de nación. Given the linguistically heterogeneous "neo-African ethnic denomination" of cabildos, members communicated in Spanish, the Afro-Cuban bozal creole, and a range of African vernaculars (Brown 2003: 27). ${ }^{5}$ Further, Palmié points out that following abolition in 1888, language-identified groups were cut off from their cultural sources in Africa, which would have created the conditions for the attrition of various vernaculars. Despite this sudden discontinuity, Otero (2010: 77) points out that culture-building was political as well as spiritual, as "in the late nineteenth century in Cuba ... 'Yoruba' cabildos sought to reconstruct a religious and nationalist discourse centered on the construction of Lucumí identity."

Part of the success of Lucumí identity in Cuba stems from Ortiz's assertion of the superiority of Yoruba "superstitions" in comparison to those of adjacent Cuban

4. Otero (2010: 34$)$ reported, "In the census of 1861, a total of 232,493 individuals were counted as free people of color on the island. Of this number, some 37,768 free people of color were listed as living in Havana."

5. Ortiz ([1916] 1987) included several distinct language groups as Lucumí, including several Yoruba dialect groups as well as peoples outside of Yorubaland, including Arará (said to be descended from Aja-Ewe languages from Ghana to Benin) and Tacuá (from Tapa, the Yoruba word for the Nupe people northeast of Yorubaland). In a more recent study, López Valdés (1990) named one hundred and thirty Lucumí subgroups, including the Bariba (northwest of the Yoruba), the Igbo in eastern Nigeria, the Hausa ("Aguza") in northern Nigeria, and the Asante ("Chante") in Ghana. 
slave groups (Ortiz [1906] 2011: 4), later declaring "lucumí or yoruba negroes, together with the Dahomeans, are the most civilized in West Africa.... Yoruba religion is also the most complex in terms of its liturgy, musical forms, instruments, chants, and sacred dances" (Ortiz 1945-1946). Such statements looped back into Afro-Cuban religious discourse and no doubt buttressed Lucumí identification with the Yoruba as well as incentivized the revision of linguistic and religious practices through exploiting contemporary Yoruba ones, which continues to this day. ${ }^{6}$

Ortiz's first venture into correlating Lucumí deities with Yoruba orishas in Nigeria, ([1906] 2011: 124-53) draws heavily on publications by the African-born missionary Samuel Crowther (1843), the American Baptist missionary Thomas Jefferson Bowen (1858), the French Catholic missionary Pierre Bouche (1880), and especially British Colonel Alfred Burdon Ellis (1894). Ortiz also triangulates African spiritual and linguistic information with lateral religious equivalents in Brazil through the writings of Raymundo Nina Rodrigues (1900). Ortiz largely follows the hierarchical scheme of Yoruba orishas reported by Bowen as well as Ellis's scheme of "Chief Gods" and "Minor Gods" ([1894] 1964: 34-84), along with their kin and conjugal relationships, although several deities are named which are little known or unknown in Cuba (at least until the 1990s, at which time the international trade of orishas opened up). ${ }^{7}$ Most of the nineteenth-century authors researching in West Africa that Ortiz referenced (many of whom were European) had researched a wide geographic range of protoYoruba dialects, and to my knowledge, none of them had formal linguistic training. Hence, it is not surprising that Ortiz used a range of spellings and orthographies in his 1906 text, long before formulas for Yoruba-Lucumí transliteration began to develop.

6. I give examples in this article of how ritual language can be revised according to contemporary Yoruba practices in quite a direct manner, but Palmié (1993: 343) conceptually frames past African identity-building in Cuba as follows: "I would thus argue for a view of African source societies not as doubtful exporters of the personnel of New World 'nations,' but as providers of models for corporate aggregation."

7. By "trade," I refer to payments for ceremonies in which initiates receive vessels containing orishas in material form.
Decades before "confirmation bias" was coined, it was Lydia Cabrera who picked up the Yoruba mantle and pioneered the compilation of Lucumí word lists from the late 1920s, yet little focus was given to seeking the derivation of words where no Yoruba equivalent could be found in a dictionary. There is indeed an obvious connection between the vocabularies and ritual practices of the Lucumí in Cuba and the Yoruba in Nigeria, but it is difficult to estimate the initial and ongoing impact of Ortiz's early publications on the knowledge formation of what is now commonly called Yoruba religion, language, and music in Cuba. ${ }^{8}$ Although a linguistic study by Olmsted (1953) concluded that the YorubaLucumí equivalence asserted by William Bascom (1950: $67 ; 1951: 17 ; 1952: 164)$ was significantly overestimated, this inconvenient evidence is usually ignored by those pushing a Yoruba-centric agenda. A corpus of literature has uncritically reinforced the notion that Lucumí is some kind of variety of Yoruba. ${ }^{9}$ A century of research initiated by Ortiz's descriptions of the language and religious constitution of the Lucumí people became both a process of (re)Yorubization and a developmental source for worshippers (Palmié 2013). ${ }^{10}$

In Ortiz's first published presentation of his transculturation theory several decades after his first publications, he acknowledged "the loss or uprooting of a preceding culture, which could be defined as partial deculturation" ([1940] 2001: 260) in the transculturation process. He did not, however, discuss language change or loss here or elsewhere as a part of that deculturation. In later texts, Ortiz ([1950] 1965) attributed the "incomprehensible and untranslatable ... unintelligible," (191) and "cryptic" (196) words in Cuba's ritual lexicons to their poetic form and content, whose "set of mystical properties" (189) and "mysterious transcendence" (190) can be sought through "secret formulas

8. See Palmié 2013 for a book-length study of this problem.

9. Most influential among these texts are (in chronological order) Angarica 2010, Cabrera 1957, Castellanos and Castellanos 1990, Mason 1992, W. Abimbola 1997, and Linguistic Data Consortium 2008.

10. See also Matory 1999, which challenges "agentless, collective memory that is usual in the representation of African culture in the Americas and at home" through research of historical literary exchanges between Nigeria and Brazil, where "written texts have become major and transformative vehicles of such cultural transmission and identity-formation" (97). 
possessed only by the favored" (214). Although the concept of untranslatability is debated within linguistics, Lucumí discourse tends not to revolve around what is and is not translatable, but rather what underlies the assertion that words and texts cannot be translated.

With a new wave of Yorubization during and since the período especial in the 1990s, African revisions of Lucumí religion and its lexicon have become increasingly creative, particularly with the upsurge of tourism (which includes some Yoruba speakers), and increased internet access enabling direct communications with Nigerians as well as online language sources and tools. ${ }^{11}$ Rather than investigating the most visible African revisionism taking place in Cuba's Ifá nigeriano religious houses and cultural institutions, ${ }^{12}$ this article brings Ortiz's translation model and its legacy of Yorubazation into the home of a santero (orisha priest) in dialogue with a Yoruba priestess, whose spiritual authority in Cuba is built on a timeless past and is largely hinged on her linguistic knowledge of Yoruba (although not Spanish or Lucumí).

\section{Translation as transculturation}

Language translation - in its scholarly and informal configurations - is one component within a complex of transculturation processes. If the power imbalances in Ortiz's time revolved around race and class inequities

11. The internet has also opened up new business possibilities for orisha devotees. Large amounts of money changes hands for commodities, information, and "technorituals" (Beliso-De Jesús 2015a: 61-65). Cyberspace has also created opportunities for unscrupulous practices. See also Brandon 2008 and Murphy 2008 for research into the impact of the internet on orisha devotion.

12. In post-1990s Cuba a Yoruba revisionist movement has developed and is mostly concentrated among Ifá divining priests known as babalawos. The most radical houses are replacing Lucumí songs, divination texts, prayers, and ritual practices with Yoruba ones and are importing copious accoutrements from Nigeria, such as cloth, sacred bead work, drums, divining paraphernalia, and organic materials used in ritual. Perhaps the most radical import is the ancestral full body mask for Egúngún. See Meadows 2017 for more detail about how Yoruba Egúngún rituals have proliferated throughout Cuba. in Cuba, religious power struggles on the island since the 1990s have arisen from a split in religious identification. On one side, the majority of devotees continue to identify with their Cuban ritual lineages and consanguineal ancestors while their African ancestors are frozen in the long-distant past. On the other side of the conflict are the priests (predominantly babalawos) who look to living Yoruba priests to bring the distant past into the present by providing the source material for their contemporary Yorubization projects.

If Ortiz's initiation of Yorubization was inadvertent in 1906 , the post-1990s movement is politically explicit and encompasses revisionist religious lineages around the country and the "Nigerian-rooted institutions" (Meadows 2017) they have influenced, endorsed, or created. Yoruba language knowledge resides at the heart of this revisionist drive, so the Cuban priests leading it are dependent on the input and educational resources of Anglophone Yoruba speakers and their mobile religious godchildren (mostly from affluent countries). In the process, the Cuban priests outwardly surrender their religious authority to all-knowing Nigerian Yoruba speakers (often regardless of whether or not the latter are orisha devotees or linguistically adept) while inwardly garnering power from their linguistic and ritual knowledge. What may not be well known to the revisionist priests, however, is that Nigerian Yoruba-speakers with whom they communicate over the internet, or who may land on the island for a visit, have varying registers of knowledge of their own language. As Nigerians are schooled in English, many educated fluent Yoruba speakers cannot write Yoruba accurately, while others who are fully literate in Yoruba may have very little knowledge of orisha religion. Additionally, many of the most knowledgeable orisha elders in Nigeria are illiterate.

After more than a century of cultural shift around Santería and Ifá, what was once transculturation between Lucumí-speaking slaves and their colonial masters has become a transatlantic transculturation between Spanish-speaking devotees adept in Lucumí utterances and Yoruba-speaking authorities. Alongside the contemporary Yoruba reversion enterprise, however, there is substantial resistance from the more "traditional" (i.e., inward-looking) devotees to the authority granted to Nigerians and their ritual and linguistic editing. What is and is not traditional, however, has an added complexity in the current religious environment in Cuba, whereby the African revisionists regard themselves to be the true traditionalists practicing "Traditional Yoruba Religion" while the majority claim to be following the 
traditional path of their ancestors. ${ }^{13}$ The zealous interventions of a growing number of Yoruba priests visiting Cuba can be met by resistance, as illustrated by some of the unfriendly experiences Doyin and I endured in Havana.

If one contemplates Cuba's changing linguistic environment during Ortiz's lifetime, there is a tension between his theory of transculturation, which recognizes the agency of subaltern groups in stimulating cultural change, and language translation, where "the translator involves the foreign text in an asymmetrical act of communication, weighted ideologically towards the translating culture" (Venuti 2000: 484-85). This statement can be applied to Ortiz's translations from the early twentieth century, at which time the asymmetry between the colonial ethnographer and his African "subjects" was much wider than it is now. But if one applies the theory of transculturation to the countless Nigerian speakers attempting to translate Lucumí texts uttered in an environment where Cubans have no tools to assess the expertise of their interpreters, are the Cuban priests still the subaltern group, and do they have any more power to inscribe the semantic meaning of their ritual lexicon than they did during Ortiz's lifetime (18811969)?

Several scholars have interrogated the methods used to back-translate Lucumí into Yoruba (e.g., Dianteill and Swearingen 2003 and Wirtz 2007), yet there has been little research about the Nigerian-Cuban social encounter. My primary objective of bringing Doyin to Cuba as a collaborative partner was to conduct a close ethnography of her social encounters in the language and religious sphere. I also engaged her in translating Lucumí song texts in the field, where I could observe her process as a transatlantic priestess searching for meaning. Michaela Wolf (1995: 123-24) reminds us:

When "translating between cultures" there is a lot of overlap between ethnography and translation, ethnography being understood as a part of cultural anthro-

13. J. D. Y. Peel (2015) further complicates the notion of "Traditional Yoruba Religion" by questioning whether nineteenth-century orisha worship should be considered a religion as very few deities were worshipped beyond specific regions and/or dialect groups. Further, he coherently argues that "Yoruba Religion" comprises Christianity and Islam, given the historical and statistical realities of the Yoruba people. pology, and therein mainly as an act of representation or rather textualization of something observed. . . Ethnography, as textualization of oral discourse, is a social act.

As a musician trained in ethnomusicology-an inherently interdisciplinary field that evolved out of musicology, linguistics, and anthropology - my understanding of "music" incorporates sound, language, and movement (from gesture to dance) and the social processes that generate and result from them. ${ }^{14}$ My research in Cuba with Doyin builds on my orisha song studies in Cuba and Nigeria since 1999. Where my previous publications presented analysis of songs collected during fieldwork and from secondary sources (e.g., Villepastour 2014, 2019), the material in this paper draws from ethnography of the actual encounters of Doyin in Cuba in a range of settings. Conversations took place during street encounters where Doyin was regularly approached by santeros and babalawos, a variety of bembés (drumming celebrations) in Havana and Regla, concerts, and in people's homes. Doyin was regularly engaged in conversations by Cubans about orisha worship in Nigeria and the Yoruba language in all of these contexts. As well as observing Doyin in this range of social and religious encounters, I watched carefully while she was also actively involved in the translation of Lucumí song texts.

My core role as ethnographer was often obscured as I was frequently tasked as a translator during Doyin's daily encounters with Cubans, as she speaks no Spanish. I do not, however, consider myself to be a translator in the formal sense, as the job's baseline requires mastery of all languages involved, in this case Spanish, Yoruba, English, and the Lucumí lexicon. Where I can only claim mastery of my first language, Doyin is fully bilingual in Yoruba and English, yet cannot understand Spanish and has only a limited linguistic, historical, and most significantly, aural knowledge of Lucumí, whose written form is more similar to Yoruba than its pronunciation. Despite my limitations in conversational Yoruba (which I studied at graduate level) and Spanish, my

14. Although beyond the scope of this paper, music analysis adds an important dimension to linguistic analysis through revealing the relative pitch (especially relevant to tone languages such as Yoruba), stress (as expressed in rhythm and phrasing), and the periodicity of natural speech (experienced in musical meter). 
working knowledge and technical grasp of Lucumí, Yoruba, and Spanish gave me the linguistic overview to assess the level of multidirectional communication (including nonverbal strategies), allowing me to identify the many assumptions and misinterpretations between Doyin and the Cubans.

\section{Transculturation in and between Osogbo and Havana}

In the scholarship addressing the recent upsurge of Nigerian religious influence in Afro-Cuban religion in Cuba and the United States (e.g., Brown 2003; Palmié 2013; Meadows 2017), little has been explored about actual encounters and power relations inside the ceremonial space. In February 2018 Doyin flew from her hometown of Osogbo into the "contact zone" of Havana. Initially coined by Mary Louise Pratt to frame her thoughts about writing, literacy, and transculturation, contact zones were described by her as "social spaces where cultures meet, clash, and grapple with each other, often in contexts of highly asymmetrical relations of power, such as colonialism, slavery, or their aftermaths as they are lived out in many parts of the world today" (Pratt 1991: 34).

Both Nigerians and Cubans live in the aftermaths of colonialism and slavery, but the nature of the historical oppression of orisha devotees differs in Nigeria and Cuba. The power asymmetry for orisha devotees in Nigeria is in relationship to the national Muslim/Christian hegemony in an environment where orisha devotees are estimated to constitute around 5 percent of the Yoruba people, who are less than a quarter of Nigeria's population. Orisha devotees in Cuba share this history of religious oppression, initially by the Christian majority and since the revolution the atheist state; however, Cuban orisha devotees are a significantly larger portion of the population than orisha devotees in Nigeria. Further, the visibility and presence of santeros and babalawos in public life have significantly grown since a 1992 constitutional amendment increased religious freedom, allowing all Christian and Afro-Cuban believers to be members of the Communist Party. For the first time since the revolution, this enabled santeros to practice openly, take up official positions in government, and wield more influence in public and political life.

The intercultural "contact zone" - in its widest context-is not only familiar to Doyin, but her life has been shaped by it. Her father, known simply as Olosun, was the Chief Priest in Osogbo during his lifetime and died in 1977 when Doyin was a child. In London in 2002, I showed Doyin a Pierre Verger photograph of an Oshun priest, which I suspected was her father. After gazing at the image during a protracted silence, she confirmed that it was indeed her father, and that she had never seen a photograph of him and would like a copy. I was surprised when this document-now tatty from almost twenty years of wear and tear-emerged from Doyin's handbag on more than one occasion during our 2018 Cuban trip. When just a small child, Doyin's father took her to his friend, Susanne Wenger (19152009), an Austrian artist who had moved to Nigeria in 1949 with her then husband, Ulli Beier. They lived in several locations in Yorubaland and settled in Osogbo in 1958 on the eve of Nigerian independence (1960). Probst (2011: 137) summarizes their timing: "By the late 1950 s and early '60s, when the Osogbo art movement started, colonial modernity had led to a steady decline in traditional Yoruba art and religion, leaving behind a spiritual and artistic vacuum into which Ulli Beier and Susanne Wenger, the two expatriates who initiated the movement, introduced new forms and injected a new artistic spirit."

Wenger underwent several initiations in the years following her arrival in the region and, after two marriages, she parented several African-born children on her own, several of whom became internationally known artists and priests. ${ }^{15}$ She had a particularly close relationship with her adopted daughter Doyin, whom she raised in her house where "most of the children were homeschooled through rituals" (Wenger, quoted by Guicheney 2000). In 1970 Wenger took over the house in Ibokun Road, which by then had become an international hub for intellectuals, several of whom were moving between Nigeria and Cuba, including Beier, Pierre Verger, who also lived on Ibokun Road for a time, and Wande Abimbola.

Doyin married into an internationally known Ifá family (from where she takes the name Faniyi). Her husband's father initiated Chief Yemi Elebuibon, whose activities in Cuba and the United States are well documented

15. The best known are Sangodare Gbadegesin Ajala, who has initiated numerous people in Brazil, Olayiwola Adigun, who is based in Germany where he leads an active religious house, and artist Yinka Nike Davies-Okundaye, who has galleries in New York, Lagos, and Osogbo. 
(Brown 2003; Palmié 2013), while her brother-in-law, Ifakayode Faniyi, has religious godchildren (people he has initiated) around the world and is a frequent visitor to the United States and Brazil. Unlike most of her siblings, Doyin progressed to formal education, earning a Certificate in Oral Literature (Obafemi Awolowo University, 1988), a BA in the Department of Linguistics and Nigerian Languages, (University of Ilorin, 2001), and an MA in African Studies (University of Ibadan, 2005). She undertook several years of $\mathrm{PhD}$ research at University of Ibadan but was unable to complete it due to her responsibilities as a Chief Priestess in Osogbo and as a mother of three and parent to numerous adopted children. Since Wenger's death in 2009, Doyin's international travels and profile have grown exponentially. "Like Adunni [Wenger], but in reverse motion, Doyin is between two cultures. She's her heir" (Guicheney 2000).

From the late colonial period and immediately after independence, this growing group of internationally mobile ethnographers, priests, and artists associated with Osogbo were able to establish a cultural center. Wenger and Beier made their views on diasporic orisha practice explicit during their conversations with me in the early 2000s. For example, Wenger declared, "The Cuban religion is like the younger brother knitting. The younger brother copies his older brother, but the jumper comes out looking different" (pers. comm., Osogbo, April 2002), ${ }^{16}$ while Beier stated that Ifá divination is not possible without Yoruba fluency (pers. comm., Sydney, April 12, 2003). Both comments situate African orisha practice at the heart of the tradition in the historical homeland, while Beier centralized language as the nonnegotiable requirement for religious authority. Further, he shared that anthropologist Melville Herskovits had berated him and Pierre Verger for "destroying laboratory conditions" through their embedded research in Africa and the diaspora. ${ }^{17}$

16. This conversation was shortly after the World Orisha Congress in Ile Ife (August 5-12, 2001).

17. In a discussion of negative views of "the foreign elements" in contemporary Yoruba art, Beier takes a swipe at Herskovits in a publication without naming him: "This attitude is typical of the more desiccated school of anthropology that does not study human societies as living and changing organisms, but believes that in order to study a 'primitive' culture successfully one must try to 'preserve laboratory conditions'” (Beier 1968: 139).
Given that Verger and Beier lived and worked in colonial Nigeria in its early independence era, I would argue that it was the colonial encounter with its multiple contact zones that was the ideal laboratory for any study of orisha religion in Nigeria and Cuba. Not only has African orisha practice changed and developed under the colonial gaze and intervention (Peel 2003), but twentieth-century Santería and Ifá practice in Cuba has been shaped by "informant voices from the Western and neo-colonial archive" (García 2014: 5). Although Ortiz did not travel to Africa, he mined this archive and the works of mobile scholars such as Herskovits and Bascom. Given the ongoing insertion of Yoruba language and ritual practice into Lucumí ceremonies by way of academic interlocutors and written outputs, it is arguable that the transculturation that shaped what Lucumí religion has become was never a binary of Cuban slave descendants and Spanish colonizers. Nigerian Yorubas have been abstractly present in Cuban orisha religion throughout the twentieth century and have been increasingly involved in person and in cyberspace since the 1990s.

Although Doyin has never been formally aligned with or active within the various Nigerian organizations that promote orisha worship in Nigeria and abroad, such as the International Congress of Orisa Tradition and Culture and the International Council for Ifá Religion, she has been enculturated into their philosophy and homeland-diaspora positionality both by way of her unique upbringing and through her ongoing proximity to leaders of the movement, such as Wande Abimbola and Yemi Elebuibon. Her tertiary education has also given her entry into academic circles, where she has been an invited speaker in various institutions, including the musée du quai Branly in Paris, Duke and Harvard Universities in the United States, and Conferência Internacional de Intelectuais da África e da Diáspora in Brazil. Doyin's social and religious background, education, and international travels almost always situate her in a pedagogical role in her encounters with foreign orisha devotees. As I had anticipated, this was both embraced and shunned in Cuba.

\section{Priestly encounters}

A week after Doyin's arrival in Havana, akpon (ritual singer) Javier Piña invited us to a bembé (drumming celebration) in Old Havana where there was to be a presentación de la iyawó, a ceremony that presents a new priest(ess) (at least three months after their initiation) 
to the sacred batá drums in a semi-public setting. ${ }^{18}$ This was the first presentation ceremony Doyin had witnessed and was one of several bembés we attended in Cuba. Beyond her high religious status in her home country and in North America, Europe, and Brazil, Doyin has a powerfully charismatic presence and dignified poise. Raised in a family of artists and an artist herself, she invariably creates a visual spectacle both at home and abroad by way of her inventive attire, which is always an elegant assemblage of sacred symbols that identify specific deities through their coded shapes, materials, and colors. Today, Doyin is wearing an outfit she designed in exquisite white cloth, and in one hand she is carrying a blood-red ostrich-skin handbag and emerging from the other hand is a human-like torso at the top of a brass bell (aja), which is routinely used to call the orisha of sexuality and motherhood, Oshun (Ọșun in Nigeria, Ochún in Cuba). Her striking face is marked by several long scars that convey her royal lineage. Adding to the drama of Doyin's entrance, she wears a large, flamboyant Yoruba head tie (gele), which she removes as we enter the house to reveal a striking sculptural hair design she originated several years ago as a postmodern twist on Yoruba ritual coiffure now seen crowning numerous Osogbo priestesses. Stiff, interlocking braids are wrapped in multicolored cotton threads and adorned with small brass fans crafted by contemporary Osogbo artists and red parrot feathers (ikóóde) used in orisha initiations.

As many orisha symbols and accoutrements are loosely cognate in Nigeria and Cuba, santeros in the room will have immediately identified Doyin as a priestess of Oshun by way of her ritual bell, decorative fans, and heavy wrist bracelets, all made from Oshun's sacred metal, and the yellow beads cascading from her neck. The thick green and maroon beads on her left wrist communicate her status as a fully initiated Ifá diviner. We had walked into the oro cantado, a section of the ceremony comprising the performance of a liturgy of songs, during which the orishas can take possession of their devotees' bodies. Doyin and I quietly moved a

18. The sacred energy of the Yoruba god of drumming, Añá (Àyàn in Nigeria), is ritually installed inside the three batá drums in a one-week consecration, and the drummers who play the consecrated drums are expected to have undergone an initiation ceremony to this drumbound spirit. Similarly, anyone "saluting" the drums by bowing and touching the forehead on each drum shell during a bembé should have already undergone the presentation ceremony. few feet into the room on the opposite side from the musicians.

Old Havana, February 17, 2018

Javier acknowledges us across the room. After standing for a few minutes, Doyin becomes uncomfortable that no one has welcomed us when we arrived.

"The first thing we do in Nigeria is bring people a chair when they arrive." I spot two low stools a few feet away and move one towards Doyin. As I return to get the second, a young woman brashly declares,

"Esta ocupado," as she drops her handbag onto the stool. Eventually a friendly face approaches us. In fluent English, Natalia tells us that she lives over the road and works as a tour guide. Some people around us start to move into gentle trances and as one person appears to be moving towards full possession, Natalia leans over to us and explains,

"In this house, we don't pay people to get possessed. The orishas come if they want to, but if they don't, it doesn't matter." A woman in the adjoining room is moving into a more dramatic trance, her head and torso convulsing back and forth as several people restrain her from entering the room with the drums. Javier sees people looking into the neighboring room and moves towards the entrance and looks around the corner, but he seems disinterested and returns to the drummers. When they play a rhythm for Oshun, Doyin and I move forward and place money in the gourd by the drummers' feet and gently retreat. Javier moves into a liturgy of songs for Oshun and as his praises become increasingly insistent, forcefully inviting Doyin's orisha into the room, she slowly shuffles towards the drummers. She dances elegantly and gracefully, and with authority. As Doyin moves closer to the drums and her energy begins to fill the room, I notice the excitement on the drummers' faces as they smile and look to one another. The man leading the musicians with the largest instrument, the iyá, probably in his mid to late sixties, suddenly unleashes more volume and the rhythmic conversations between the drummers become slightly faster and denser. As Doyin begins to rotate, several people gravitate to her with upheld mobile phones but they are intercepted by a young man, who gestures them to stop. Doyin catches my eye and summons me. Short of breath and croaky, she says,

"I need water." I rush deeper into the house and quickly return with a full plastic cup. She gulps a mouthful then tips the rest over the crown of her head and a joyous smile lights up her face as she spins in accelerating rotations with her other hand extended upward and sounding her brass bell. Unable to rely on the stylized gestures of Cuban santeros, the musicians study her face and bodily gestures and respond with building 
volume, tempo, and emotion. As people standing on the footpath outside and further inside the house hear the growing intensity of the music, an inpouring of bodies through both doors quickly fills the room until it is densely packed and hot. Javier chooses well-known songs with short calls that are easy to copy, and for the first time the congregants make a big sound as they join the chorus with eyes on Doyin. I scan room to see how people are responding to the spectacle; some look excited and intensify their singing, gesturing, and dancing, while others look quietly curious and reserved. I spot an old woman by the inner doorway wearing a traditional gingham skirt and holding a mop. She doesn't look pleased and passes the mop to a young woman, who moves towards us, first drying the floor around Doyin then poking the mop between her dancing feet in a surreal sacred choreography. I look across the room and note the old woman's displeasure as she watches Doyin with pursed lips and shakes her head. In my peripheral vision I see Doyin's body changing, apparently oblivious to the dancing mop. Seeing that trance is approaching, Javier calls in Chachalokefun, a batá rhythm that often tips the devotee over the edge into spirit possession. I start to feel concerned as I see Doyin moving deeper into trance, knowing that she can be possessed for hours or even days. Will anyone here know what to do? I touch Javier's arm and gesture to cool things with a downward movement of my open palm. He brushes his fingers across his throat indicating, "Kill it?" and I nod. Javier stops the drummers with a downward hand gesture.

I guide Doyin to the back and we sit on two low stools, vacated by onlookers. As she starts to recover, a little girl, perhaps two or three, approaches Doyin and stares intensely into her eyes, level with her own. They stay locked in this gaze for a couple of minutes until the girl walks away. Doyin says to me, "She saw Ọșun. Children can see things more directly than adults."

Regarding it taboo to speak negatively about people, Doyin later shared that she experienced people at the bembé as "closed." The next day, she attended her second bembé, which was held in a tiny front room in Central Havana. Doyin and I arrived at the house with another group of musicians, and following a similarly aloof reception to the previous day from the few congregants, the drummers began to play the oro seco, the first drummed sequence without vocals in a bembé. Once again, Doyin found it difficult to understand why we were not offered chairs, particularly given that the three low stools in the room were occupied by young men. She spotted an inflated car tyre leaning against a wall and asked me to roll it towards her. As we sank into the rubber together, she said, "We sit on these in Nigeria." I didn't notice any response to our pragmatism, but as soon as the musical sequence was over and Doyin and I moved outside to chat to the musicians, I saw a young man rolling our round chair out the front door and into a neighbor's house. I told Doyin that we should leave, which she strongly resisted as she said it would be rude to do so. After convincing her that I felt we were not welcome, we quietly slipped away and walked for an hour to our accommodation as the musician who invited us to the ceremony had extorted our last cash with a taxi scam on our arrival.

If Cuban and Nigerian orisha devotees share a religious, linguistic, and cultural inheritance, as asserted by Ortiz and contemporary African revisionists in Cuba, what explains the evident social fissure between Doyin and other devotees in these two ordinary ceremonial settings? As we were not acquainted with anyone prior to these fleeting encounters, I had no opportunity to clarify the uncomfortable nonverbal responses to Doyin at both bembés. I am, however, able to speculate after two decades of ethnographic and ceremonial experience in Cuba, where friends and trusted research respondents have felt comfortable enough to articulate difficult feelings about the increasing influence and presence of Yoruba priests in Cuba.

While some Cubans declare Nigerian Yoruba practice to be "the root" of Santería or even the same religion, others deem it an entirely different spiritual system. Perhaps the most cutting words I have heard in resistance to the growing Yoruba revisionism in Cuba came from Matanzas-based santero and musician Luis Bran: "We feel like we're being colonized again" (pers. comm., Matanzas, March 10, 2013). ${ }^{19}$ The overarching

19. The issues surrounding African interventions in Cuban orisha traditions have many parallels in Brazil. Argentinian anthropologist Juana Elbein dos Santos, who is known for Yorubizing Candomblé, published a scathing critique of religious interlocutors: "A large part of the black populations of Bahia ... makes Africa and Africans idealized paradigms of knowledge and extraordinary powers ... any student from Nigeria, Benin or any other region will be transformed into a revered idol, a source of values and knowledge, which will enable positions within the community to be enhanced. The Brazilians open their houses of worship and their wallets - usually in dollarsfor these 'connoisseurs,' thus casting doubt upon their own heritage and their own knowledge, handed down from generation to generation. . . It will not be these 
limitation I observed between Doyin and the Cubans was the language barrier, where Doyin spoke no Spanish and few Cubans speak English. Despite the fact that Lucumí is said to be a dialect of Yoruba, Cubans cannot use it to converse with Yoruba speakers. This explicit linguistic gap reinforced the cultural and interpretive chasm, which emerged in numerous ways.

It is possible that the muted responses aroused by Doyin's powerful presence signaled innocuous feelings such as curiosity and awe along with more circumspect reactions fueled by suspicion, threat, or even hostility. Letting her stand did not necessarily signal that she was unwelcome as the social practice of offering mature guests a chair on entry where the ceremony is taking place is not a convention in Cuba unless the person is elderly or incapacitated. The space is usually populated by standing or dancing bodies, while those needing to sit would move to an adjacent room. Sitting down, however, may have been interpreted as a disregard for Cuban religious conventions. Aspects of her attire may also have provoked uneasiness, such as the beaded bracelet that identified her as a female Ifá diviner, known as iyanifá (from the Yoruba iyánifá). The first initiations of women into the Cuban divining cult began in the early 2000s and remain contentious among the majority of babalawos and santeros, and so remain at the heart of the controversy of Nigerian interventions in Cuba. ${ }^{20}$ Additionally, Doyin's hair adornment of red parrot feathers may also have caused apprehension. In Cuba they are used in ritual crowns or directly on the shaved head in closed initiation ceremonies, but may also signal an "explicit connection to the problems of witchcraft and its corresponding antidotes" (Brown 2003: 180). Although the feathers also have associations with witchcraft in Nigeria (Apter 1992: 113), for Oshun

'new connoisseurs,' who arrived during the last decade on our beaches, themselves the product of another historical colonial experience...., who can interfere with our tradition, pointing out, correcting, publishing profane books, performing spectacular divining practices and inventing traditions. Our tradition was created and continually recreates itself from inaugural principles, but with its own dynamic, participating dialectically in the Brazilian social reality" (Santos 1991-92: 2, as quoted by Capone 2010: 244).

20. See Beliso-De Jesús $2015 b$ for a study of the history, dynamics and disputes concerning the initiation of iyanifás in Cuba. priestesses in Osogbo, the feathers' meaning is benign; it is yet another symbol of their goddess, whose cosmic house is decorated with ikóóde.

Beyond the orisha's visual symbols that are were mutually recognizable, the Cuban ceremonies we attended together were markedly different from anything Doyin routinely experiences at home. The presentation ceremony has no equivalent in Nigeria, and the common practice of hiring a spirit medium to enact a stylized and theatrical trance performance in a ceremony, as is common in Cuba, would be unthinkable in Nigeria. I have yet to witness or hear of feigned trance in Nigerian ceremonies, whereas Cuban devotees readily complain about its ubiquity. Just as post-revolutionary choreographed stage performances in Cuba frequently dramatize the gestures of spirit possession, the stylized choreography of staged possession has now looped back into domestic ceremonies (Hagedorn 2001). Cuban drummers are among the most critical of fake possession, particularly as enacted by the hired spirit mediums referenced by Natalia, hence the excitement of the musicians in Old Havana when Doyin began to move into trance.

The challenging experiences of our first two bembés were offset by extremely warm and positive experiences in a religious house in Regla, led by santero and oriaté Francisco Ung Villanueva (b.1949). ${ }^{21}$ From our first visit to Francisco's house in Regla, Doyin was treated as a highly honored guest (see Figure 1). This dynamic was explicit from our first visit.

\section{Regla, February 14, 2018}

Doyin and I are greeted by a smiling a middle-aged woman, one of Francisco's ahijados [religious godchildren] as she unlocks the iron gate. She beckons us to enter but Doyin asks her to bring some water to sprinkle on the sidewalk and the path between the gate and Francisco's doorstep, explaining that this should be done when an Oshun priest is visiting. As the ahijada recedes to follow Doyin's instructions, I see Francisco disappearing up the steps with his dog, not anticipating that Doyin is also a dog lover. As we enter the salon Francisco reappears and prostrates at Doyin's feet. She seems surprised, as he is older than she, but she bends and beckons him to rise and embraces him. When we sit, Francisco declares,

"I’m nervous!"

21. An oriaté is a master cowrie shell diviner and ritual specialist who leads orisha initiations. 


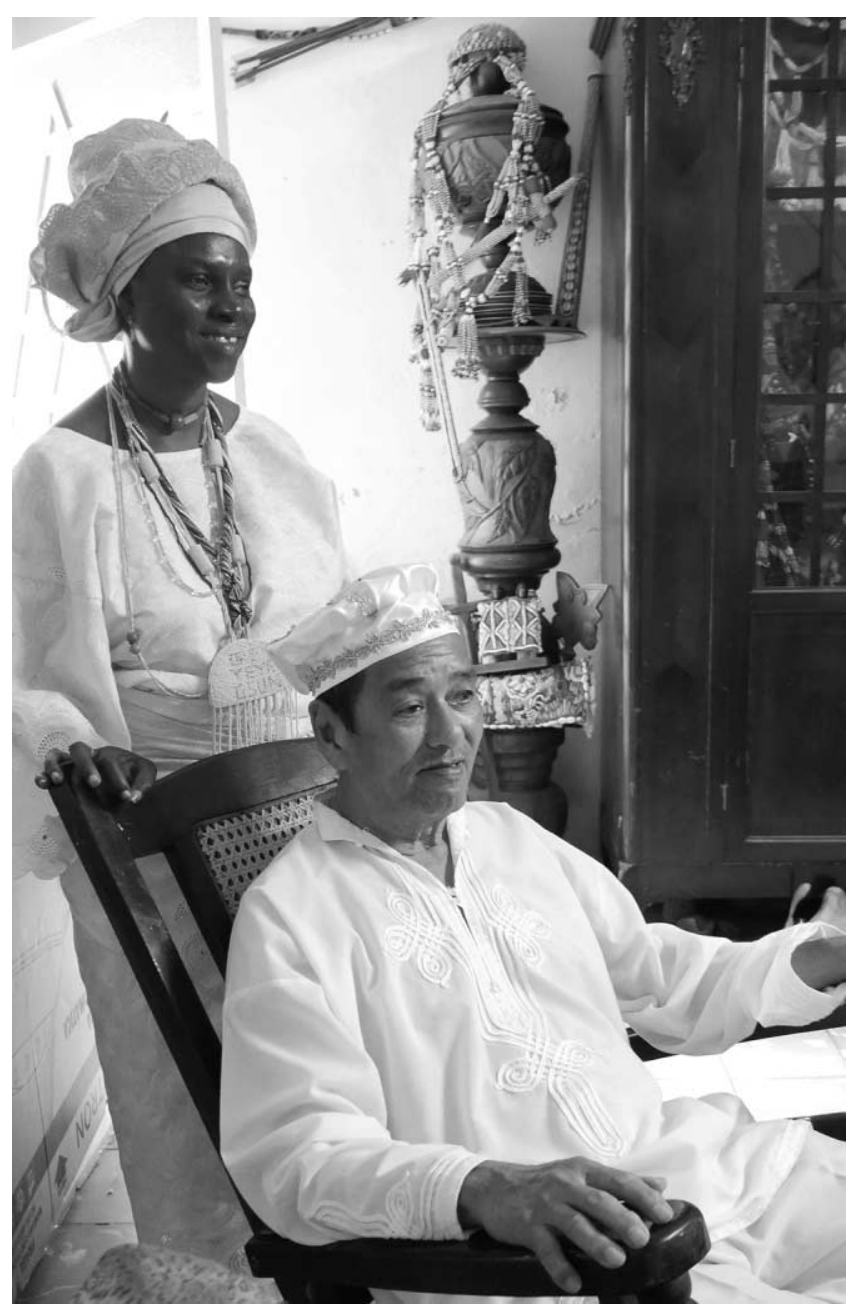

Figure 1: Doyin Faniyi and Francisco Ung, Regla, February 23,2018 . Photograph by author.

“Oh, don't be nervous. I've been longing to come to Cuba for many years since hearing the music." Francisco explains to Doyin that he has Yoruba lineages from the Iyebú [İjẹbu] and Egwado [Ëgbádò] dialect groups and that his yubona [second godparent] was born from a Yoruba-speaking mother and was initiated in 1912.

"When I was a child, I was told that there was no time for language. I want to improve my dialect."

Doyin fully obliged Francisco's language aspirations, having assumed a pedagogical orientation even before entering the front gate. After this initial meeting, we were very fortunate to be invited to participate in the initiation of a new priest (known as kariocha). During this one-week ceremony, drumming celebrations, and other time spent in the house, Doyin's assumed identity as spiritual teacher and language consultant, however, did not arise from arrogance, as may easily be assumed by Cubans who feel hostile to Nigerian involvement in Santería and Ifá. As people in Europe, North America, and Brazil visit Ibokun Road in Osogbo, Nigeria as well as fly Doyin around the globe to teach, lecture, and consult, she is accustomed to people deferring to her so it felt natural and logical for her to assume an instructional role.

To use a metaphor of bodies of water, the Ọșun river flows through the center of Osogbo's sacred groves and winds down to Lagos Lagoon, where it meets other tributaries and flows out into the Atlantic Ocean, which carried people, spirits, and ideas to what became the Yoruba diaspora. This unidirectional geographical flow and historical logic not only shaped the thinking of Fernando Ortiz and his intellectual partners and secondary sources from Brazil, Europe, and Africa, but it has enculturated generations of orisha devotees in Nigeria and Cuba into assuming a one-way knowledge flow from the un- or little-changing homeland and ever-changing diaspora (Matory 2011). This perspective has been reinforced by intergenerational foreign intellectuals and orisha worshippers converging at the house on Ibokun Road for research and religious knowledge, initiations, and training. This sacred domestic site (and similar ones like it in Nigeria led by well-connected priests) may be better understood as a metaphorical confluence of many rivers rather than a source. In terms of translation as transculturation, these domestic hubs are transculturation contact zones. Like Doyin, Francisco has an international reputation as a knowledgeable priest and artisan and is known far and wide for his exquisite spiritual beadwork. He regularly receives local and foreign devotees and researchers into his own transculturation contact zone and, like Doyin, has religious godchildren around the world.

The decomplexified Yoruba origin narrative was enacted through many hours of questions from Francisco and other members of his religious family towards Doyin. She was occasionally asked about comparative ritual practices, but most of her time was taken up with translating Lucumí words, phrases, song lyrics, and enquiries about their ritually received names, yet Doyin asked few questions about Lucumí utterances and ritual practices. Nonetheless, despite his keen interest in the Yoruba language and transatlantic practices, Francisco's religious house does not fall into the category of casa nigeriana, where the default position would be to insert Yoruba linguistic 
content into songs, divination texts, and prayers in part or in full, and to modify or replace Lucumí ritual practices with cognate contemporary Yoruba ones, or even introduce rites never previously practiced in Cuba, such as the full body masks of the ancestors, Egungun. ${ }^{22}$ Rather, Francisco's main interest is to fully maintain the traditions he has inherited while endeavoring to shed light on the various African lexicons uttered in his house, which include Arará and Luango along with the different dialect lexicons of Lucumí. ${ }^{23}$

\section{Translating the ancestors}

Before arriving in Cuba with Doyin in 2018, I devised a two-tiered song translation method to explore the processes Nigerian and Cuban priests call upon in the search for semantic meaning in Lucumí sacred texts. The linguistic outcome of the two stages, however, is not in any way intended to assess or comment on Doyin's translation competence. Rather, the method was designed to reveal common assumptions by individuals from the source and target language groups regarding the translatability of Lucumí and the expected reliability of literal (word-for-word) translation. My close observation of the various translation steps and behaviors also laid bare the social dynamic and the ensuing balance of social and religious power. My object was not to produce authoritative Spanish translations of Lucumí song texts, although given Francisco's linguistic aspirations and his high respect for Doyin, I knew that might be an unavoidable biproduct of the research.

After Doyin's first visit to Regla, I asked her to transcribe and translate several Lucumí songs I had recorded a week before in a ceremony for the ancestors led by the akpon (ritual singer) Rayner Leyva in Francisco's house. I expected that Doyin would have some difficulties with finding Yoruba cognates to the Lucumí utterances, as one is a true-tone language (where relative pitch determines meaning) and the other a lexicon which has lost

22. Meadows (2017) has done considerable research throughout Cuba on the introduction of Nigerian Egungun rites.

23. The Arará spiritual tradition and lexicon is said to derive from Aja-Ewe language groups from Ghana to Benin, while Loango was a central-west African state spanning what is now western Republic of the Congo, southern Gabon, and Cabinda. its tonal system and has superimposed stress from Spanish. ${ }^{24}$ The intonation of Lucumí words or groups of words is arbitrary when spoken, yet there are some religious songs performed on both sides of the Atlantic where the Lucumí song melodies follow the contours of their Yoruba equivalents and so reveal Lucumís lost speech tones (as explained in Villepastour 2019). ${ }^{25}$ For this article, I have chosen a different kind of song, where the Lucumí melodic setting displays no vestiges of the tonal structures of Yoruba.

This song is performed in a ceremony for the egun (ancestral spirits, from the Yoruba word Eégún). To my knowledge it has no Nigerian equivalent and uses a scale and melodic structure one does not expect to hear in Yoruba songs. The musicological technicalities of this are beyond the scope of this paper, but in layman's terms, Yoruba song melodies generally use a five-note scale to help disambiguate the language's three speech tones, whereas the Cuban song in my example uses six pitches and a melodic structure atypical of Yoruba song style. Further, the Cuban song is strophic, meaning that different segments of text use the same melody (as in, for example, different verses of a pop song with different lyrics set to an identical or very similar melody). As Yoruba melodies must not deviate too far from the relative speech tones of ordinary speech in order to remain intelligible, the melodies cannot be strophic as this would jumble the speech tones and therefore the text's meaning. Each stanza of the example has an AABA structure where the bold text of $B$ varies in each strophe:
A: Bobo wa niche
A: Bobo wa niche
B: Ala iki Olodumare
A: Bobo wa niche

24. Where Spanish usually stresses the penultimate syllable (unless an acute accent designates a stress on a different syllable), Lucumí more frequently stresses the final syllable. Stressed syllables in Lucumí, however, only have a random relationship to the high tones of Yoruba, which use the identical diacritic.

25. Villepastour (2014) explains how Yoruba natural speech is set to melody, while Villepastour (2019) presents the technicalities of how many Cuban orisha songs use scales, phrasing, and melodic structures that resemble Yoruba musical features. In many cases, Lucumí song melodies have even retained the relative speech tone structure of the Yoruba language despite language loss in Cuba. 
The varying words of Line B correspond to the presentation of pre-prepared plates of food that are presented to the ancestral altar as part of the ritual action. (See Figure 2, where only the varying text is presented from Row 3 on). These varying words in Line B are also performed to the same melody in each strophe (some with slight rhythmic variations to accommodate the differing number of syllables), which again would not be the case in a Yoruba melody as the pitch contour would be molded around the relative speech tones of ordinary speech. Unlike many other Lucumí songs, where the melodic style resembles Yoruba musical conventions,

\begin{tabular}{|c|c|c|c|c|c|c|c|}
\hline & \multirow[b]{2}{*}{$\mathbf{A}$} & \multicolumn{2}{|c|}{ FIRST TRANSLATION } & \multicolumn{4}{|c|}{ SECOND TRANSLATION } \\
\hline & & B & C & D & $\mathbf{E}$ & $\mathbf{F}$ & G \\
\hline & $\begin{array}{l}\text { Sung Lucumí } \\
\text { (RL/FU) }\end{array}$ & $\begin{array}{c}\text { Lucumi } \\
\downarrow \\
\text { Yorùbá } \\
\text { (DF) }\end{array}$ & $\begin{array}{c}\text { Yorùbá } \\
\downarrow \\
\text { English } \\
\text { (DF) }\end{array}$ & $\begin{array}{c}\text { Lucumí } \\
\downarrow \\
\text { Spanish } \\
\text { (FU/RL) }\end{array}$ & $\begin{array}{c}\text { Spanish } \\
\downarrow \\
\text { English } \\
\text { (AV) }\end{array}$ & $\begin{array}{c}\text { English } \\
\downarrow \\
\downarrow \\
\text { Yorùbá } \\
\text { (DF/AV) }\end{array}$ & $\begin{array}{c}\text { Yorùbá } \\
\downarrow \\
\text { English } \\
\text { (DF/AV) }\end{array}$ \\
\hline 1 & $\begin{array}{l}\text { Bobo } \\
\text { wa niche } \\
\text { (x 2) }\end{array}$ & $\begin{array}{l}\text { Ggbogbo } \\
\text { wa ríje }\end{array}$ & $\begin{array}{l}\text { All of us } \\
\text { get to eat }\end{array}$ & $\begin{array}{c}\text { Todo } \\
\text { lo que } \\
\text { te cocinado }\end{array}$ & $\begin{array}{l}\text { Everything } \\
\text { was cooked } \\
\text { for you }\end{array}$ & $\begin{array}{l}\text { Ggbogbo } \\
\text { wa ní sèé }\end{array}$ & $\begin{array}{l}\text { Everything } \\
\text { we cooked }\end{array}$ \\
\hline 2 & $\begin{array}{c}\text { ala iki }(\mathrm{RL}) \\
\text { ala iqui }(\mathrm{FU}) \\
\text { Olodumare }\end{array}$ & $\begin{array}{c}\text { àsìkí } \\
\text { Olódùmarè }\end{array}$ & $\begin{array}{l}\text { blessings } \\
\text { from } \\
\text { Olodumare } \\
\text { [God] }\end{array}$ & $\begin{array}{l}\text { flores } \\
\text { Olodumare }\end{array}$ & $\begin{array}{l}\text { flowers } \\
\text { Olodumare }\end{array}$ & $\begin{array}{l}\text { òdòdó } \\
\text { Olódùmarè }\end{array}$ & $\begin{array}{l}\text { flowers } \\
\text { Olódùmarè }\end{array}$ \\
\hline 3 & eya se le & eja sèlé & torn fish & pescado cocinado & cooked fish & eja sèlé & cooked fish \\
\hline 4 & $\begin{array}{l}\text { ochinchin (RL) } \\
\text { ochin chin (FU) }\end{array}$ & ọsinșin & $\begin{array}{l}\text { melon seed } \\
\text { soup }\end{array}$ & $\begin{array}{l}\text { huevos, hierbas, } \\
\text { cebolla, tomate }\end{array}$ & $\begin{array}{l}\text { eggs, herbs, } \\
\text { onion, tomato }\end{array}$ & TRANSLIT. & $\begin{array}{l}\text { SIMILAR } \\
\text { GLOSS }\end{array}$ \\
\hline 5 & $\begin{array}{l}\text { akara } \\
\text { [bibo] }\end{array}$ & àkàrà & $\begin{array}{l}\text { fried bean } \\
\text { cakes }\end{array}$ & pan & bread & $\begin{array}{l}\text { búrédi } \\
\text { [English } \\
\text { loan word] }\end{array}$ & bread \\
\hline 6 & kukunduku & kúkúndùkú & $\begin{array}{l}\text { sweet } \\
\text { potato }\end{array}$ & boniato & sweet potato & TRANSLIT. & SAME GLOSS \\
\hline 7 & $i c h u$ & $i s ̣ u$ & boiled yam & $\begin{array}{c}\text { ñame o malanga } \\
\text { hervida }\end{array}$ & $\begin{array}{l}\text { boiled taro } \\
\text { root or yam }\end{array}$ & TRANSLIT. & $\begin{array}{l}\text { SIMILAR } \\
\text { GLOSS }\end{array}$ \\
\hline 8 & amala & àmàlà & $\begin{array}{l}\text { yam flour } \\
\text { porridge }\end{array}$ & harina de maíz & $\begin{array}{l}\text { cornmeal } \\
\text { [porridge] }\end{array}$ & TRANSLIT. & $\begin{array}{l}\text { SIMILAR } \\
\text { GLOSS }\end{array}$ \\
\hline 9 & $\begin{array}{l}\text { ewa pupua }(\mathrm{RL}) \\
\text { ewá pupua }(\mathrm{FU})\end{array}$ & èwà pupa & red beans & frijoles colorado & red beans & TRANSLIT. & SAME GLOSS \\
\hline 10 & $\begin{array}{l}\text { ewa ere }(\mathrm{RL}) \\
\text { ewá ere }(\mathrm{FU})\end{array}$ & èwà èrèé & $\begin{array}{l}\text { mashed } \\
\text { beans }\end{array}$ & frijoles caritas & $\begin{array}{l}\text { black-eyed } \\
\text { beans }\end{array}$ & TRANSLIT. & $\begin{array}{l}\text { SIMILAR } \\
\text { GLOSS. }\end{array}$ \\
\hline 11 & $\begin{array}{l}\text { ewo funfun (RL) } \\
\text { ewó fun fun (FU) }\end{array}$ & èwà funfun & $\begin{array}{l}\text { white } \\
\text { beans }\end{array}$ & $\begin{array}{c}\text { bolletas de arroz, } \\
\text { bolas o torres } \\
\text { de arroz }\end{array}$ & $\begin{array}{l}\text { rice buns, } \\
\text { rice balls, } \\
\text { or rice towers }\end{array}$ & èwó funfun & roasted yam \\
\hline 12 & ila & ilá & okra & quínbombó & okra & TRANSLIT. & SAME GLOSS \\
\hline 13 & eñi adie & oyin & honey & huevos de gallina & chicken eggs & eyin adie & chicken eggs \\
\hline
\end{tabular}

Figure 2a: Translation of egun song. 


\begin{tabular}{|c|c|c|c|c|c|c|c|}
\hline & & FIRST TR & NSLATION & & SECOND TR & ISLATION & \\
\hline & $\mathbf{A}$ & B & C & D & $\mathbf{E}$ & $\mathbf{F}$ & G \\
\hline & $\begin{array}{l}\text { Sung Lucumí } \\
\text { (RL/FU) }\end{array}$ & $\begin{array}{c}\text { Lucumi } \\
\downarrow \\
\text { Yorùbá } \\
\text { (DF) }\end{array}$ & $\begin{array}{c}\text { Yorùbá } \\
\downarrow \\
\text { English } \\
\text { (DF) }\end{array}$ & $\begin{array}{c}\text { Lucumí } \\
\downarrow \\
\text { Spanish } \\
\text { (FU/RL) }\end{array}$ & $\begin{array}{c}\text { Spanish } \\
\downarrow \\
\text { English } \\
\text { (AV) }\end{array}$ & $\begin{array}{c}\text { English } \\
\downarrow \\
\downarrow \\
\text { Yorùbá } \\
\text { (DF/AV) }\end{array}$ & $\begin{array}{c}\text { Yorùbá } \\
\downarrow \\
\text { English } \\
\text { (DF/AV) }\end{array}$ \\
\hline 14 & ado & ata & chili pepper & $\begin{array}{c}\text { gofio } \\
\text { [maiz tostado] }\end{array}$ & roasted corn & àgbadọ́ & corn \\
\hline 15 & $\begin{array}{l}\text { uñeng }(\mathrm{RL}) \\
\text { uyen (FU) }\end{array}$ & iyán & $\begin{array}{l}\text { pounded } \\
\text { yam }\end{array}$ & $\begin{array}{l}\text { comidal } \\
\text { comer }\end{array}$ & $\begin{array}{l}\text { food/ } \\
\text { to eat }\end{array}$ & ònjẹ̣ & food \\
\hline 16 & $\begin{array}{l}\text { eko (RL) } \\
\text { ekó (FU) }\end{array}$ & èkọ & $\begin{array}{c}\text { corn } \\
\text { porridge in } \\
\text { banana leaf }\end{array}$ & $\begin{array}{c}\text { maíz } \\
\text { fermentadas en } \\
\text { hoja de plátano }\end{array}$ & $\begin{array}{l}\text { fermented } \\
\text { maize in a } \\
\text { banana leaf }\end{array}$ & TRANSLIT. & SAME GLOSS \\
\hline 17 & $\begin{array}{l}\text { omi tutu RL) } \\
\text { omi tutu (FU) }\end{array}$ & omi tútù & cool water & agua fría & cold water & TRANSLIT. & SAME GLOSS \\
\hline 18 & sará & sàráà & $\begin{array}{l}\text { charitable } \\
\text { gift of food }\end{array}$ & $\begin{array}{l}\text { refresco con } \\
\text { azucar oscuro } \\
\text { y cordial }\end{array}$ & $\begin{array}{l}\text { drink made with } \\
\text { dark sugar and } \\
\text { cordial }\end{array}$ & sará & $\begin{array}{l}\text { drink made } \\
\text { from maize }\end{array}$ \\
\hline 19 & awara & àwa náà & us too & leche & milk & wàrà & milk or cheese \\
\hline 20 & omi ereke & omi ìrèké & $\begin{array}{l}\text { sugarcane } \\
\text { juice }\end{array}$ & agua con azúcar & $\begin{array}{l}\text { water with } \\
\text { sugar }\end{array}$ & TRANSLIT. & $\begin{array}{l}\text { SIMILAR } \\
\text { GLOSS }\end{array}$ \\
\hline 21 & $o b i$ & obì & kola nut & coco & $\begin{array}{l}\text { coconut [used } \\
\text { for divination] }\end{array}$ & TRANSLIT. & $\begin{array}{l}\text { SIMILAR } \\
\text { GLOSS }\end{array}$ \\
\hline 22 & oti sé & obì sẹ & split kola nut & vino seco & dry wine & otísá & $\begin{array}{l}\text { alcoholic } \\
\text { drink dried } \\
\text { in the sun }\end{array}$ \\
\hline 23 & omi bona & omi gbóná & hot water & agua caliente & hot water & TRANSLIT. & SAME GLOSS \\
\hline 24 & achá & ata & chili pepper & tabaco & tobacco & $\begin{array}{l}\text { tábà [English } \\
\text { loan word] }\end{array}$ & tobacco \\
\hline 25 & atana & ànàmọ́ & sweet potato & vela & candle & $\begin{array}{l}\text { atàná } \\
\text { issáná } \\
\text { àtanpa }\end{array}$ & $\begin{array}{l}\text { firelight } \\
\text { match } \\
\text { lamp }\end{array}$ \\
\hline 26 & $\begin{array}{c}\text { okon kan }(\mathrm{RL}) \\
\text { okokan }(\mathrm{FU})\end{array}$ & òkọọkkan & one-by-one & un corazón & one heart & okàn kan & one heart \\
\hline
\end{tabular}

Figure 2b: Translation of egun song (continued).

this egun melody is probably not derived from a Yoruba song but may have had Lucumí words superimposed onto a melody from a different cultural musical system. The song is in a call-response AABA form, where the akpon leads, then the coro (chorus) of congregants repeats the same words and melody. As accompaniment, the akpon pounds the floor with a bacucú, an egun staff about the size of a walking cane wrapped in cloth with at least nine small bells (chaworó) attached.

Since Doyin had no ceremonial experience in Cuba and does not speak Spanish, so was unfamiliar with the Hispanicized transliterations of Yoruba to Lucumí, she 
was responding to the disembodied sounds on the recording, stripped of the visual cues that later helped her deduce the religious and social context of the vocabulary. Additionally, she was disadvantaged as the melody gave no clues about the Yoruba speech tones, as explained above. Nevertheless, she quickly back-translated most of the Lucumí words (Column A of Figure 2) into Yoruba (B) and English (C). While it was relatively easy for her to identify many of the Lucumí nouns for ritual food, numerous Yoruba words and phrases she suggested did not semantically correspond with the Lucumí or the ritual symbolism and context of the Cuban ceremony.

After collecting Doyin's Yoruba back-translations and English glosses (Columns B and C), I then took the song lyrics through a second translation process. First, I collected the written Lucumí (Column A) and Spanish glosses (D) from Francisco (FU) and Rayner (RL) and translated them into English (E). ${ }^{26}$ The differences in their spelling, word divisions, and translations exemplify the variations typical of Lucumí, which has no standard orthography. In the rows where Doyin's initial English translations of the Yoruba (Column C) were substantially different from my English translations (E) of Francisco and Rayner's Spanish glosses (D), Doyin and I reviewed the Yoruba (F) and the English translations (G). Shaded boxes in the second translations in Columns D to G indicate significant differences from the first translations in Columns B and C. The translations that correspond are left in white, including glosses that indicate a similar understanding of a word, even if the Nigerian culinary ingredients are substituted with Cuban ones, such as in the case with ochinchin/ochin chin (Row 4).

While many of the Lucumí words were easily recognizable for Doyin, others posed transliteration, semantic, and contextual problems. For example, she backtranslated oti sé (Row 22) to obi sẹ́. Yoruba /b/ is not usually transliterated to /t/ in Lucumí, but the akpon, Rayner (RL), later told us that sé is not a Yoruba word but is Spanish syllable of seco (dry). Similarly, Doyin back-translated achá (tobacco) as ata (chili pepper) (Row 24), but Lucumí /ch/ would normally be a transliteration of Yoruba /ș/ (as in ship). Doyin possibly

26. I collected the written Lucumí from Rayner and the Spanish glosses from Francisco and Rayner while in Cuba. Some months later, I emailed Francisco a Spanish draft of this article, which he returned with numerous corrections, including different written versions of some Lucumí words (Column A) and in some cases Spanish glosses (D). made these linguistic leaps as chili is used in Yoruba offerings but not in Cuban ones, while conversely, tobacco is a common Cuban offering but is unheard-of in Nigerian orisha rituals. While Doyin back-translated tobacco with the English loan word tábà in her second round, at the time neither of us knew the Yoruba word for tobacco/snuff, aásarà or its contraction aásaà (as spelled by Abraham 1970: 70), which predictably transliterates to Lucumí as achá. ${ }^{27}$ This is particularly relevant to my discussion of translation as transculturation, since Ortiz had rolled tobacco into his first-published exposition of his transculturation theory, Cuban counterpoint: Tobacco and sugar ( [1940] 1947). Chapter 7 describes the leaf's "universal transculturation" (294) across class, racial, linguistic and geographical lines from the Antilles to European nations and through their trade routes and colonies around the world. Attempting to track achá back to its Yoruba root also illustrates the frequently nonlinear connections between Yoruba and Lucumí vocabulary.

Crowther (1843) may have been the first to list the Yoruba word and English loanword for tobacco or snuff as aashar (75) and tabba (84). In a later, coauthored edition (Crowther and Vidal 1852), the spellings așara (46) and tabbà (269) reflect developments in Yoruba orthography, while a new entry for "rock-salt" explains, "Kanhun li ommo Haussa, asara li ommo Oyibo. . . . Rock salt is the produce of Haussa; tobacco is the produce of the men beyond the sea" (177). The etymology of aásarà is uncertain but would have originally been a neologism in response to the introduction of tobacco by foreigners. ${ }^{28}$

If aásarà, aáșaà, or its transliteration achá were in common use at some point in Cuba, their absence from printed sources is curious given the ubiquitous use of cigars and cigarettes as sacrificial offerings and the use of tobacco smoke in cleansing rituals. Given the timelines of tobacco's history in Nigeria and Cuba, it is possible that achá entered the Lucumí lexicon in the twentieth century. It is notable that the word is entirely missing from Ortiz's 1940 history of tobacco in Cuba, which describes the rapid transfer of its consumption and ritual

27. I am grateful to one of the anonymous reviewers for alerting me to the Yoruba word aásaà in J.B.O. Losi’s İtàn Ekkó (History of Lagos) (1913), who reports that tobacco was introduced to the city in the mid-eighteenth century.

28. Linguist Túndé Adégbọá (pers. comm., December 30, 2020) suggests that aásarà and its contraction aásaà mimic the sneezing that follows consuming snuff. 
use from Cuba's indigenous peoples to African slaves. Lucumí terms for tobacco are also absent from most dictionaries and word lists, one exception being the appearance of asará in Cabrera (1957: 61). There is no mention, however, of tobacco in her gloss, which possibly indicates semantic broadening of a Yoruba word: "sustituye al sacrificio cuando el sacerdote no puede ofrecerles aves o animals" (substitute sacrifice when the priest cannot offer them [the orishas] birds or animals). There is also an entry for achá "tabaco" (25) followed by several word combinations and formations that incorporate achá. For example, achadúdu, "cigarrillo" (cigarette), obviously derives from the Yoruba words aáșà (tobacco) and dúdú (black/dark), whereas Yoruba speakers use the English loan word sigá (a false cognate of cigar) for cigarette and tábà for cigar. The first cigarette factory appeared in Havana in 1853, well before the introduction of cigarettes into Nigeria in the 1890s and Nigeria's first cigarette factory in Doyin's hometown of Osogbo in 1933. Achadúdu may well be a Cuban word formation that has no Yoruba precedent or equivalent, suggesting either Lucumís former generative capacity or even Cabrera's scholarly intervention.

Doyin also interpreted ado (Row 14) as ata (chili), which could be a viable transliteration. She could not, however, offer a Yoruba cognate after hearing the $\mathrm{Cu}$ bans' gloss, but I suggest that àgbàdo (maize/corn) has been shortened to ado. Candles (atana, Row 25) are not used as offerings in Nigerian practice as in Cuba, so resulted in the unrelated word ànàmọ́ (sweet potato). In her second translation, Doyin offered three suggestions but could not find a neat cognate. She also found several near homophones, such as sará/sàráà (Row 18) and okon kan/ọkọọkan (26), neither of which semantically correspond to the Spanish (Column D). Sàráa is a particularly interesting example as it is an Arabic loan word for a Muslim practice. In other instances, Doyin assumed similarsounding words in her first translations, such as ewo/ èwà (Row 11), eñi adie/oyin (13), uñeng/iyán (15), and awara/àwa náà (19) but her English translations had distinct meanings from the Spanish.

I was particularly interested in Line 2 of the song, ala iki/iqui Olodumare, where there were too many words in the Spanish translation to make sense of the Lucumí. Doyin's Yoruba translation, àsikí, seemed far-removed from the Lucumí phonemes and context, but when I asked Rayner about the meaning of this line, he and others in the house were insistent that it referred to presenting flowers to Olodumare (God). While flowers are a common offering in Cuba, they do not feature in
Nigerian orisha practice. The Cubans did not know the Yoruba word for flowers, òdòdó, or a Lucumí equivalent, ${ }^{29}$ and as homophonic conflict resulting in lexical change is common in Lucumí, I suggested that there may be some linguistic slippage from òdòdó to Olódùmarè. As Rayner started weeping, Francisco turned to me and declared, "The work you're doing is so important," and then he also burst into tears. I swung around to look for Doyin, and saw her standing with her back to us, her shoulders convulsing as she wept to the wall.

While this collective expression of intense emotion revealed the deep personal investment this linguistic encounter had for the three priests, I feared that they may have interpreted my linguistic suggestion as the uncovering of a monumental transatlantic truth. However, the translation process I have described and the data presented in Figure 2 cautions that Lucumí translation is too speculative a venture to assume truth. Of the twenty-six song lines Doyin attempted to translate from the recording, she determined twelve Yoruba lines with a similar or the same gloss (approximately 46 percent) and fourteen semantically unrelated Yoruba lines resulting in differing Spanish and English glosses (approximately 54 percent). These disparities can only partly be explained by divergences in ritual materials (as in Lines 2, 18, 22, 24, and 25). To use a principle from second-language learning, Doyin's listening was weighted towards top-down processing, where she depended on the background knowledge and concepts of her own ritual practice rather than bottom-up processing, where the listener relies on auditory input and sound recognition. Had Doyin been more familiar with Lucumí pronunciation and the common transliterations in written form, it would have been easier for her to aurally identify the links between spoken Yoruba and Lucumí. If the two translations are considered wordby-word, out of the thirty-eight words in Column A (with the repeated words eliminated), twenty-one (approximately 53 percent) of the Yoruba words in Column B semantically correspond. This small sample would not be taken seriously by linguists, who demand significant numbers to be able to elicit scientific conclusions. Nevertheless, while my study of this and many other songs is qualitative and ethnographic rather than quantitative,

29. Francisco later offered that the Lucumí word odódó refers to the color pink. This may be a corruption of ọdundún, the Kalanchoe (Crassulaceae) shrub with pink flowers (Abraham 1970: 505). 
it could be harnessed as a method for a larger-scale study.

It was an uncomfortable moment for me as I witnessed these very knowledgeable priests responding with such intense emotion, believing I had reached into the forgotten past. Not wanting to be responsible for inventing the future, the next day I implored Rayner to think very carefully before changing the way he performs the songs Doyin and I had analyzed, as our Yoruba propositions would not only be different from the way his ancestors performed the songs, but what if our speculative back-translations and glosses are wrong? Despite expressing my reservations to Francisco and Rayner, my two-tiered method appeared not to have influenced anybody. Francisco continued to sing songs to Doyin over the following days and appeared to accept her translations as authoritative. When I returned to Regla in September 2018, I tripped over my ethnographic footprint once again when Francisco enthusiastically shared that he had integrated a song that Doyin had performed during the initiation we had attended earlier in the year. Doyin sang as the initiate was being ritually bathed in the river at the beginning of the ceremony to consecrate a new priest, one of the most sacred moments in the one-week ceremony. After we have all joined the ancestors, perhaps a future transatlantic researcher will discover this song in Regla as evidence of the Yoruba collective memory.

\section{Conclusion}

Since Ortiz declared Lucumí to be Yoruba in 1906, Lucumí song texts have been in a permanent state of revision. As I have illustrated, Cuban devotees, their Nigerian translation partners, and many scholars proceed from the understanding that Lucumí derives entirely from Yoruba and so can be fully understood through juxtaposing their contemporary vocabularies. While linguists have long established the dynamic character and fast-changing nature of language, the ongoing modification of Lucumí is of a different order. Ortiz's presumed Yoruba default more than a century ago became the blueprint for the scholars that followed (such as Lydia Cabrera) and the devotees and aficionados who employ the same translation model. With the upsurge of educated devotees both inside and outside of Cuba in the second half of the twentieth century, there has been a proliferation of crude Lucumí glossaries compiled by non-Yoruba scholars, devotees, and enthusias- tic musicians using Yoruba dictionaries. As non-Yoruba speakers continue to align written Lucumí words with Yoruba ones regardless of their uttered sounds (as was the case with Ortiz), this literal translation approach (which rarely progresses from word to sentence level) has collectively resulted in a nonstandardized array of Yorubized words and interpretations which have served to reinforce speculative Lucumí-Yoruba cognates. With the emerging power and influence of post-1990s casas nigerianas and the growing influence of the individuals who lead them and institutions aligned with them (such as The Yoruba Association), efforts to replace Lucumí texts with Yoruba ones will continue with full force regardless of my research.

The primary problem with translating Lucumí into Yoruba or even comparing the two, however, is that one is an apple (lexicon) and the other an orange (language). Wolf (1995: 131) proposes:

As far as the specific question of asymmetric power relations in translating between cultures is concerned, a new concept of translation is necessary which needs to create a new awareness of the relationship between "strong" and "weak" languages. Discourses in different cultures are not autarchic but develop within social fields of power and privilege.

Yoruba is unambiguously the "strong" language, with around thirty million speakers and a large corpus of literature and linguistic research to support it. Lucumí is linguistically "weak" in terms of the fact it is no longer spoken and has never had a standardized orthography, due to the lack of focused linguistic research. If language is at the core of culture and transculturation, Lucumí worshippers are the subaltern group in relationship to Yoruba speakers. The speculative products of backtranslated Lucumí song texts often result in "copying that originates" (Geertz 1986: 380), where new meanings are created. But regardless of their semantic (in)accuracy, Yoruba translations of Lucumí songs have the potential to grant legitimacy and convey authenticity, which relies on freezing fluid performance practices.

All of the musicians with whom I have interacted in Cuba over two decades understand the importance of Ortiz's work, but few are familiar with the content of his writings. I have seen tatty documents passed around that have plagiarized blocks of Ortiz text with names of contemporary personalities woven into the original historiography. Such documents have been presented to me as recorded oral histories, known as tratados. As 
Ortiz's influence on contemporary religious musicians is so monumental - whether or not they know it - the nonacademic contingent tends not to view his output critically, which adds to its enduring power.

The powerful communicative possibilities of music are now well documented; cross-disciplinary research proves that music can communicate certain kinds of messages in real time without the need for intermediaries in ways that language cannot (see, for example, Cross 2014). Music's linguistic component, however, eclipses the fluid and egalitarian potential of musical encounters. Translation has historically been a way that colonizers would "force their menu of culture onto the dominated showing very little interest in what the dominated power itself produces" (Danyté 2012: 4). It has also served as one of the most important tools of religious conversion, as continued by the Christian missionary linguists in SIL (the Summer Institute of Linguistics). Where nineteenth-century Yoruba-speaking missionaries translated the bible into Yoruba to convert orisha worshippers to Christianity, many twentiethcentury Yoruba-speaking orisha missionaries-cumcolonizers are now translating Lucumí (along with Brazil's orixa lexicon) into modern Yoruba with the aim of integrating "the younger brother's knitting" into a Nigerianled World Religion. Just as linguistic knowledge can socially elevate visiting Nigerians, their Cuban partners aspire to the very same sociolinguistic power. In doing so, Cubans forgo their own agency and submit to an asymmetrical process of linguistic assimilation, which is better described by acculturation than Ortiz's theory of transculturation.

\section{Acknowledgments}

I thank the two anonymous reviewers for their critical readings. I am also grateful for the suggestions and corrections by Francisco Ung and Doyin Faniyi.

\section{References}

Abimbola, Kola. 2006. Yorùbá culture: A philosophical account. Birmingham: Iroko Academic Publishers.

Abimbola, Wande. 1997. Ifá will mend our broken world: Thoughts on Yoruba religion and culture in Africa and the diaspora. Roxbury: Aim Books.

Abraham, Roy Clive. 1970. Dictionary of modern Yoruba. London: University of London Press Ltd.
Angarica, Nicolas Valantin. 2010. El lucumí al alcance de todos. n.p.: Editorial Nuevo Mundo.

Apter, Andrew H. 1992. Black critics and kings: The hermeneutics of power in Yoruba society. Chicago: University of Chicago Press.

Ashcroft, Bill. 2001. Post-colonial transformation. London and New York: Routledge.

Ayorinde, Christine. 2004. Afro-Cuban religiosity, revolution, and national identity. Gainesville: University Press of Florida.

Barber, Karin. 1981. "How man makes God in West Africa: Yoruba attitudes towards the 'Orisa.”' Africa 51 (3): 724-45.

Bascom, William. 1948. William Russell Bascom papers, circa 1930-1979. Berkeley: Bancroft Library, University of California.

1950. "The focus of Cuban Santería." Southwestern Journal of Anthropology 6 (1): 64-69.

20.

. 1951. “The Yoruba in Cuba.” Nigeria magazine, 14-

. 1952. "Yoruba acculturation in Cuba." Les AfroAméricains. Mémoires de l'Institute Francais D’Afrique Noire 27: 163-68.

Beier, Ulli. 1968. Contemporary art in Africa. London: Pall Mall.

Beliso-De Jesús, Aisha M. 2015a. Electric Santería: Racial and sexual assemblages of transnational religion. New York: Columbia University Press.

. 2015b. "Contentious diasporas: Gender, sexuality, and heteronationalisms in the Cuban iyanifa debate." Signs 40 (4): 817-40.

Benejam, Joan. 1885. Vocabulario menorquín-castellano. Ciutadella: Imprenta de Salvador Fábregues.

Bouche, Pierre. 1880. Étude sur la langue Nago [ou Yorouba]. Études Catholiques. Bar-le-Duc: Philipona.

Bowen, Thomas Jefferson. 1858. Grammar and dictionary of the Yoruba language: With an introductory description of the country and people of Yoruba. Washington, DC: Smithsonian Institution.

Brandon, George E. 2008. "From oral to digital—Rethinking the transmission of tradition in Yorùbá religion.” In Òriṣà devotion as world religion: The globalization of Yorùbá religious culture, edited by Jacob K. Olupona and Terry Rey, 448-69. Madison: University of Wisconsin Press.

Brown, David. 2003. Santería enthroned: Art, ritual, and innovation in an Afro-Cuban religion. Chicago: University of Chicago Press. 
Cabrera, Lydia. 1957. Anagó: Vocabulario lucumí (el Yoruba que se habla en $(u b a)$. La Habana: Ediciones C.R.

Capone, Stefania. 2010. Searching for Africa in Brazil. Durham, NC: Duke University Press.

Castellanos, Jorge, and Isabel Castellanos. 1990. Cultura afrocubana III: Las religiones y las lenguas. Miami: Ediciones Universal.

Cross, Ian. 2014. "Music and communication in music psychology." Psychology of Music 42 (6): 809-19.

Crowther, Samuel. 1843. Vocabulary of the Yoruba language. London: Church Missionary Society.

Crowther, Samuel, and Owen Emeric Vidal. 1852. A vocabulary of the Yoruba language. London: Seeleys.

Danyté, Milda. 2012. “Translation and other transcultural acts: Resistance to language imperialism in the age of English." Otherness: Essays and Studies 3 (1): 1.

Dianteill, Erwann, and Martha Swearingen. 2003. "From hierography to ethnography and back: Lydia Cabrera's texts and the written tradition in Afro-Cuban religions." Journal of American Folklore 116 (461): 273-92.

Ellis, Alfred Burdon. (1894) 1964. The Yoruba-speaking peoples of the slave coast of West Africa. Chicago: Benin Press, Ltd.

Eltis, David. 2004. "The diaspora of Yoruba speakers, 1650 1865: Dimensions and implications." In The Yoruba diaspora in the Atlantic world, edited by Toyin Falola and M. D. Childs, 17-39. Bloomington/Indianapolis: Indiana University Press.

Fagborun, J. Gbenga. 1994. The Yoruba koiné-Its history and linguistic innovations. München: Lincom Europa.

Garcia, David F. 2014. "Contesting anthropology's and ethnomusicology's will to power in the field: William R. Bascom's and Richard A. Waterman's fieldwork in Cuba, 1948." MUSICultures 40: 2.

Geertz, Clifford. 1986. The religion of Java. Chicago: University of Chicago Press.

Guicheney, Pierre. 2000. Susanne Wenger, un portrait. http:// pierre-guicheney.eklablog.com/susanne-wenger-un-por trait-p417306. Accessed February 1, 2020.

Hagedorn, Katherine J. 2001. Divine utterances: The performance of Afro-Cuban Santería. Washington and London: Smithsonian Institution Press.

Linguistic Data Consortium. 2008. Global Yoruba lexical database Vol.1.0. Philadelphia: Linguistic Data Consortium.
López Valdés, Rafael L. 1990. "Notas para el estudio etnohistórico de los esclavos Lucumi de Cuba." In Estudios Afro-Cubanos: Selección de lecturas, 4 volumes, edited by Lázara Menéndez, vol. 2: 312-47.

Losi, John B. 1913. Iwe itan Eko. Lagos: Tika Tore Printing Works.

Mason, John. 1992. Orin òrìsà: Songs for selected heads. Brooklyn: Yorùbá Theological Archministry.

Matory, J. Lorand. 1999. "The English professors of Brazil: On the diasporic roots of the Yorùbá nation." Comparative Studies in Society and History 41 (1): 72-103.

. 2011. Black Atlantic religion: Tradition, transnationalism, and matriarchy in the Afro-Brazilian Candomblé. Princeton and Oxford: Princeton University Press.

Meadows, Ruthie. 2017. Ifá tradicional nigeriano: The polemics of "re-Yorubized" spirituality in Cuban sound. $\mathrm{PhD}$ diss., University of Pennsylvania.

Murphy, Joseph. 2008. "Òrìsa traditions and the internet diaspora." In Orișa devotion as world religion: The globalization of Yorùbá religious culture, edited by Jacob K. Olupona and Terry Rey, 470-84. Madison: The University of Wisconsin Press.

Nina Rodrigues, Raymundo. 1900. L'animisme fétichiste de nègres de Bahia. Bahia: Reis.

Olmsted, David. L. 1953. "Comparative notes on Yoruba and Lucumí.” Language 29 (2): 7-64.

Ortiz, Fernando. 1895. Culecció d'els mal-nòms de Ciutadella.

. (1906) 2011. Hampa Afrocubana: Los negros brujos. San Juan: Editorial Nuevo Mundo.

(1916) 1987. Los negros esclavos. La Habana: Editorial de Ciencias Sociales.

. (1940) 1947. Cuban counterpoint: Tobacco and sugar. Knopf Doubleday Publishing Group. Kindle Edition.

1945-1946. "La música religiosa de los yorubas entre los negros cubanos." Estudios afrocubanos 5: 19-60.

(1950) 1965. La africanía de la música folklórica de Cuba. La Habana: Editora Universitaria.

Ortiz, Fernando, and Robin D. Moore. 2018. Fernando Ortiz on music: Selected writing on Afro-Cuban culture. Philadelphia: Temple University Press.

Otero, Solimar. 2010. Afro-Cuban diasporas in the Atlantic world. Rochester: University of Rochester Press.

Palmié, Stephan. 1993. "Ethnogenetic processes and cultural transfer in Caribbean slave populations." In Slavery in the 
Americas, edited by Wolfgang Binder, 337-63. Würzburg: Königshausen und Neumann.

. 2013. The cooking of history: How not to study AfroCuban religion. Chicago: University of Chicago Press.

Peel, J. D. Y. 2003. Religious encounter and the making of the Yoruba. Bloomington: Indiana University Press.

2015. Christianity, Islam and orisa religion: Three traditions in comparison and interaction. Berkeley: University of California Press.

Pratt, Mary Louise. 1991. "Arts of the contact zone.” Profession 33-40.

Probst, Peter. 2011. Osogbo and the art of heritage: Monuments, deities, and money. Bloomington: Indiana University Press.

Ramos, Miguel W. 2011. Orí Eledá mí ó . . si mi cabeza no me vende. Miami: Eleda Org. Publications.

Santos, Juana Elbein dos. 1991-1992. "A sedução dos novos africanes." Siwaju 5-6: 2-3.
Venuti, Lawrence. 2000. "Translation, community, utopia." In The translation studies reader, edited by Lawrence Venuti, 468-88. London and New York: Routledge.

Villepastour, Amanda. 2014. "Talking tones and singing speech among the Yoruba of Southwest Nigeria." Jahrbuch des Phonogrammarchivs der Österreichischen Akademie der Wissenschaften 44: 29-47.

. 2019. "The Cuban lexicon Lucumí and African language Yoruba: Musical and historical connections." In The changing world language map, edited by by Stanley D. Brunn. Dordrecht: Springer Science + Business Media B.V. https://doi.org/10.1007/978-3-319-73400-2_183-2.

Wirtz, Kristina. 2007. "How diasporic religious communities remember: Learning to speak the 'tongue of the oricha' in Cuban Santería." American Ethnologist 34 (1): 108-26.

Wolf, Michaela. 1995. “Translation as a process of power: Aspects of cultural anthropology in translation." In Translation as intercultural communication: Selected papers from EST Congress-Prague, edited by Mary Snell-Hornby, Zuzana Jettmarová, Klaus Kaindl, 123-33. Amsterdam: Benjamins.

Amanda Villepastour is an ethnomusicologist specializing in Yoruba orisha music in Nigeria and Cuba. She is a Reader at Cardiff University, Wales, UK.

Amanda Villepastour VillepastourAV@cardiff.ac.uk 